\title{
Intralesional corticosteroid injection as an effective treatment method for oral lesions: a meta-analysis
}

\author{
Narges Gholizadeh", Maryam-Sadat Sadrzadeh-Afshar ${ }^{\circledR 2}$, Nafiseh Sheykhbahaei ${ }^{3 *}$
}

\author{
${ }^{1}$ Oral \& Maxillofacial Medicine Department, School of Dentistry, Tehran University of Medical Sciences, Tehran, Iran, \\ ${ }^{2}$ Oral \& Maxillofacial Medicine Department, School of Dentistry, Aja University of Medical Sciences, Tehran, Iran, ${ }^{3}$ Oral \& \\ Maxillofacial Medicine Department, School of Dentistry, Tehran University of Medical Sciences, Tehran, Iran
}

\begin{abstract}
Intralesional corticosteroid injection (ICSI) is known as one of the main methods used for treating a wide range of lesions. It also results in a high concentration of drugs at lesion sites, with minimal systemic absorption. Thus, this study aimed to provide a review of the intralesional corticosteroid injection (ICSI) indications in the treatment of oral lesions. To this end; relevant key words were searched in the databases of PubMed, Google Scholar, Scopus, ScienceDirect, and UpToDate in the present study. Accordingly, the results of a total number of 62 case reports or case series articles were used in this study and the positive therapeutic effects of intralesional corticosteroid injection (ICSI) in 23 common oral lesions were reported. The most common type of intralesional steroid in the treatment of oral lesions was triamcinolone. No significant difference was also observed in terms of pain in patients following the use of steroid alone or in combination with anesthetic agents; moreover, the reported side effects of this method were exceptionally rare and transient. It was concluded that the intralesional corticosteroid injection (ICSI) could be one of the effective therapeutic methods with no significant problems in many oral lesions such as inflammatory, immunologic, and vascular ones due to its higher therapeutic effects than other topical forms of steroids and fewer side effects than systemic corticosteroid.
\end{abstract}

Keywords: Intralesional corticosteroid injection. Triamcinolone. Betamethasone. Oral lesions. Oral disorders. Steroid injection.

\section{INTRODUCTION}

Intralesional corticosteroid injection (ICSI), introduced as a medical treatment in 1951, has become one of the main methods used alone or in combination with other procedures for treating a wide range of diseases as well as benign and malignant proliferations in the head and the neck (Egbert et al., 2001; Buckmiller, Francis, Galde, 2008; Ffrooz, Tehranchia-Nia, Ahmed, 1995). The ICSI leads to a high concentration of drugs at lesion sites, with minimal systemic absorption; therefore, it has no common side effects of systemic form or even reduces them (Goldman, 1962; Saravanan et al., 2014). However, in cases wherein high or repeated doses of injection are required, systemic corticosteroid considerations such as hypertension, heart failure, uncontrolled diabetes,

\footnotetext{
*Correspondence: N. Sheykhbahaei. Oral \& Maxillofacial Medicine Department, School of Dentistry, Tehran University of Medical Sciences, Tehran, Iran. Tel: +98-9128090967 / Fax: +98-2181633501. E-mail: dsheykhbahaei@gmail.com
}

acute peptic ulcer, depression, severe psychosis, and active fungal and bacterial infections must be taken into account. In addition, the ICSI is preferable to the topical corticosteroids such as creams, ointments, mouthwashes, gels, and foams due to bypassing of mucous membranes, reduced risk of mucosal atrophy, higher drug concentrations, and longer durability in lesion sites (Laisuan et al., 2017). Nowadays, various medications are available for the ICSIs; however, physicians commonly prescribe triamcinolone and betamethasone derivations. The most important point in this therapeutic approach is that the efficacy and the potential complications of the injection are dependent on its usage method (Ffrooz, Tehranchia-Nia, Ahmed, 1995). This injection is performed at offices without special supplies and equipment. Prior to injection; the history of any allergies, systemic problems, and the use of medications such as aspirin and warfarin must be taken from patients. Although the local anesthesia can be used at the site, it is not usually necessary because 
the pain created by the ICSI is similar to the injection of the anesthetic substance (Saravanan et al., 2014). If the injectable material is a suspension, it must be shaken well before injection. Corticosteroids, either pure or diluted, with saline or anesthetics can be further applied. In most oral lesions, 0.1 to $0.2 \mathrm{~mL}$ of the substance is also injected into four sides of a lesion, and it is normally recommended not to increase the total dosage more than $2 \mathrm{~mL}$ in each session. For this purpose, insulin syringe is the most suitable injection device. Moreover, the forms used for the ICSI do not need to be kept in refrigerator thanks to their high shelf life (Richards, 2010).

Immediate side effects of the injection include pain, bleeding, infection, and allergic reaction, as well as delayed complications including atrophy of skin or mucous membranes, and hyper- or hypo-pigmentation of the lesion site (Saravanan et al., 2014; Laisuan et al., 2017). Although these indications are not very common, the possible cause of complications is the lymphogenous spread of corticosteroid suspension, which brings about dermal and epidermal changes such as thinning of the epithelium, loss of rete ridges, necrosis of epithelial and small blood vessels, interference with synthesis of melanin from melanocytes, reduction of mucopolysaccharides, and loss of elastic properties of tissues. In this line, the incidence of tissue atrophy depends on injection depth and local concentration obtained after injection (Hengge et al., 2006; Friedman, Butler, Pittelkow, 1988; Schetman, Hambrick, Wilson, 1963). The ICSI in children can also cause abnormalities in their growth and immune system (Buckmiller, Francis, $\&$ Glade, 2008). Although the occurrence of these complications is very rare, it leads to some worries in some patients and reduces levels of collaboration in treatments. Therefore, the efficacy of this therapeutic approach depends on the effective communications by physicians with patients along with awareness concerning benefits and possible complications (Del Rosso, Friedlander, 2005). The ICSI is a safe and costeffective process. Accordingly, the employment of this method in the treatment of skin lesions has been highly reported and approved. Nevertheless, no comprehensive review has been so far carried out on applying it in oral lesions, administration patterns, drug types and dosages, and treatment outcomes. Considering the relatively high prevalence rates of oral diseases and the potential of benefits of this method, it can be utilized in the treatment of numerous oral lesions. Thus, this study aimed to present a review of the ICSI indications and treatment details in oral lesions to provide more reliable evidence for clinicians.

\section{MATERIAL AND METHODS}

The data collection was fulfilled through searching in the databases of PubMed, Google Scholar, Scopus, ScienceDirect, and UpToDate using relevant keywords including corticosteroid injection, intralesional injection, triamcinolone injection, betamethasone injection, oral lesions, oral disorders, and steroid injection, alone or in combination. In this search, no time limit was considered, the last access to different platforms was in September 2018, and the search results were restricted to articles published in English. The inclusion criteria for the articles composed of:

1 - Clinical trial articles

2 - Case reports or case series articles

3 - Treatment of oral lesions or structures related to oral cavity; e.g. salivary glands, temporomandibular joint, lips, sinuses and oropharynx, no skin, or other sites of the body.

4 - Intralesional injection of steroids and no other forms of corticosteroids

\section{RESULTS}

Following the completion of the search process, 600 abstracts were obtained and about 200 relevant abstracts were reviewed and nearly 80 full-text articles in PDF format were selected. In total, 62 articles were included in this study.

\section{DISCUSSION}

The most common causes to use corticosteroid drugs in oral medicine are their anti-inflammatory, antiproliferative, immunosuppressive, and vasoconstrictive effects which appear to be largely mediated by several mechanisms such as functioning on stromal capillaries to decrease erythema, directing regulation of corticosteroidresponsive genes by steroid-receptor complex, having indirect control over transcription through blockage of effects of other transcription factors such as NF-kB, inhibiting transcription of various pro-inflammatory cytokine genes including interleukin IL-1, IL-2, IL-6, interferon gamma (IFN- $\gamma$ ), and tumor necrosis factoralpha, stimulating expression of anti-inflammatory cytokines genes such as transforming growth factor-B and IL-10, making shifts in T-helper type 1 (TH1) to $\mathrm{TH} 2$ ratio, and decreasing trafficking of lymphocytes to lesion sites by diminishing vascular permeability and inhibiting proliferation of various cell types including $\mathrm{T}$ lymphocytes (Norris, 2005). Therefore, steroids are mostly 
employed in treatment of disorders that are inflammatory, hypersensitivity reactions against auto-antigens, as well as vascular lesions. It is noteworthy that the ICSI cannot alter the nature and the primary mechanisms that lead to the disease, but rather have palliative effects and suppress the immune system (Saravanan et al., 2014). In this study, it was proposed to provide a list of oral lesions that were likely to be treated by the ICSI. The details of the treatment protocol for each lesion along with treatment results were also reported in Table I.

TABLE I - List of articles that applied ICSI to treatment oral lesions

\begin{tabular}{|c|c|c|c|c|c|c|c|c|}
\hline Author \& Year & Type of Lesion & Type of ISCI & Does of ISCI & $\begin{array}{c}\text { Number of } \\
\text { ISCI }\end{array}$ & $\begin{array}{c}\text { Intervals of } \\
\text { ISCI }\end{array}$ & $\begin{array}{c}\text { Result of } \\
\text { treatment }\end{array}$ & Follow up & Side effects \\
\hline $\begin{array}{l}\text { Agha- } \\
\text { Hosseini et al., } \\
2016\end{array}$ & CPLA & $\begin{array}{l}\text { Triamcinolone } \\
40 \mathrm{mg} / \mathrm{mL}\end{array}$ & & 3 & $2 w$ & $\begin{array}{l}\text { Complete } \\
\text { regression }\end{array}$ & $6 \mathrm{~m}$ & none \\
\hline $\begin{array}{l}\text { Buckmiller, } \\
\text { Francis, Glade, } \\
2008\end{array}$ & hemangiomas & $\begin{array}{c}\text { Triamcinolone and } \\
\text { betamethasone }\end{array}$ & 40 and $6 \mathrm{mg} / \mathrm{cm}^{3}$ & $1-3$ & $6-25 w(12 w)$ & $\begin{array}{l}11 \text { lesions complete } \\
\text { resolution }\end{array}$ & $6 \mathrm{~m}$ & $\begin{array}{l}4 \text { Patients failure } \\
\text { to thrive }\end{array}$ \\
\hline $\begin{array}{l}\text { Meeuwis et al., } \\
1990\end{array}$ & hemangiomas & Methylprednisolone & $20-40 \mathrm{mg}$ & $1-5$ & & $\begin{array}{l}\text { Complete } \\
\text { regression. }\end{array}$ & $6 \mathrm{~m}$ to $5 \mathrm{y}$ & $\begin{array}{l}\text { Pneumonia, slight } \\
\text { growth, acne } \\
\text { Retardation, and } \\
\text { fluffy Hair growt }\end{array}$ \\
\hline $\begin{array}{l}\text { Farmand, } \\
\text { Kuttengerg, } \\
1996\end{array}$ & lymphangioma & $\begin{array}{l}\text { Triamcinolone } \\
\text { (instilled through the } \\
\text { suction drain) }\end{array}$ & $\begin{array}{c}10 \mathrm{mg} / \mathrm{kg} \\
(30-160 \mathrm{mg})\end{array}$ & $1-2$ & & $\begin{array}{c}\text { completely } \\
\text { disappeared in } 1 \\
\text { case, residual tumor } \\
\text { excised }\end{array}$ & $1-4 y$ & None \\
\hline Luo, Gan, 2013 & $\begin{array}{l}\text { lymphatic } \\
\text { malformations }\end{array}$ & $\begin{array}{c}\text { Triamcinolone } \\
\text { acetonide } \\
(50 \mathrm{mg} / 5 \mathrm{~mL})+ \\
\text { Pingyangmycin } \\
0.625 \mathrm{mg} / \mathrm{mL} \\
\end{array}$ & $5 \mathrm{~mL}$ & 8 & 2e4 weeks & $\begin{array}{c}\text { pingyangmycin } \\
\text { with triamcinolone } \\
\text { was more effective } \\
\text { than pingyangmycin } \\
\text { alone }\end{array}$ & - & None \\
\hline $\begin{array}{l}\text { Parisi, Glick, } \\
\text { Glick, } 2006\end{array}$ & $\mathrm{PG}$ & $\begin{array}{l}\text { Triamcinolone } \\
40 \mathrm{mg} / \mathrm{mL}\end{array}$ & $\begin{array}{l}(0.1 \mathrm{~mL} \text { with } \\
0.5 \mathrm{~mL} \text { of } 0.5 \% \\
\text { bupivicaine }\end{array}$ & 6 & $\begin{array}{c}1 \& 2 \text { inj weekly, } \\
\text { and } 4 \text { inj bi- } \\
\text { weekly }\end{array}$ & $90 \%$ resolved & $10 \mathrm{w}$ & None \\
\hline $\begin{array}{l}\text { De La Rosa } \\
\text { García, } 2006\end{array}$ & PG & Triamcinolone & $5 \mathrm{mg}$ & 3 & - & complete resolution & - & none \\
\hline $\begin{array}{l}\text { Adenis- } \\
\text { Lamarre et al., } \\
2009\end{array}$ & PG & Triamcinolone & & & & & & \\
\hline $\begin{array}{l}\text { Dolanmaz et al., } \\
2016\end{array}$ & $\mathrm{CGCG}$ & $\begin{array}{l}\text { Triamcinolone }+ \\
0.5 \% \text { marcaine }+ \\
\text { epinephrine }\end{array}$ & $3.5 \mathrm{~mL}$ & 6 & Weekly & $\begin{array}{l}4 \text { complete } \\
\text { resolution, } 2 \text { Partial } \\
\text { recovery, } 1 \text { did not } \\
\text { response }\end{array}$ & $39 \mathrm{~m}$ & None \\
\hline $\begin{array}{l}\text { Nogueira et al., } \\
2010\end{array}$ & CGCG & $\begin{array}{l}\text { Triamcinolone } \\
(20 \mathrm{mg} / \mathrm{mL})+ \\
2 \% \text { lidocaine }\end{array}$ & $0.1 \mathrm{~mL} / \mathrm{cm}^{3}$ & 6 & bweekly & $\begin{array}{l}15 \text { complete } \\
\text { resolution, } 4 \text { Partial } \\
\text { recovery, } 2 \text { did not } \\
\text { response }\end{array}$ & $4-8 \mathrm{y}$ & None \\
\hline $\begin{array}{l}\text { Sezer et al., } \\
2005\end{array}$ & CGCG & $\begin{array}{c}\text { Triamcinolone } \\
(10 \mathrm{mg} / \mathrm{mL})+\text { lidocaine } \\
2 \%\end{array}$ & $4 \mathrm{~mL}$ & 6 & Weekly & complete resolution & $3 Y$ & None \\
\hline $\begin{array}{l}\text { Da Silva } \\
\text { Sampieri et al., } \\
2013\end{array}$ & CGCG & $\begin{array}{c}\text { Triamcinolone }+ \\
\text { Articaine }\end{array}$ & $2 \mathrm{~mL}$ & 6 & Weekly & complete resolution & $3 Y$ & None \\
\hline $\begin{array}{l}\text { Carlos, Sedano, } \\
2002\end{array}$ & CGCG & $\begin{array}{c}\text { Triamcinolone } \\
(10 \mathrm{mg} / \mathrm{mL},+ \\
\text { Lidocaine } 2 \% \\
\text { orBupivacaine } 50 \%\end{array}$ & 3-6 mL & $4-20$ & $\begin{array}{l}\text { every } 15 \text { days- } \\
\text { every } 3 \text { weeks }\end{array}$ & complete resolution & $2-7 y$ & None \\
\hline Haldar, 1976 & $\begin{array}{l}\text { Cheilitis } \\
\text { glandularis }\end{array}$ & $\begin{array}{l}\text { Triamcinolone } \\
1.5 \mathrm{mg} / \mathrm{mL}\end{array}$ & $\begin{array}{c}2 \text { to } 3 \mathrm{mg} \text { in } \\
10 \text { to } 15 \text { Places }\end{array}$ & 10 & $\begin{array}{l}4 \text { weekly and } \\
2 \text { biweekly, } \\
2 \text { monthly, } 2 \\
\text { bimonthly }\end{array}$ & complete resolution & $8 \mathrm{~m}$ & None \\
\hline $\begin{array}{l}\text { Sugaya, } \\
\text { Migliari, } 2018\end{array}$ & $\begin{array}{l}\text { Cheilitis } \\
\text { glandularis }\end{array}$ & $\begin{array}{c}10 \mathrm{mg} \text { triamcinolone } \\
\text { suspension } \\
0.1 \% \text { tacrolimus } \\
\text { ointment) }\end{array}$ & & 2 & $\begin{array}{l}\text { Monthly } \\
\text { Twice daily, } 2 \text { w }\end{array}$ & $\begin{array}{l}\text { completely } \\
\text { resolving }\end{array}$ & $1 \mathrm{y}$ & None \\
\hline
\end{tabular}


TABLE I - List of articles that applied ICSI to treatment oral lesions (cont.)

\begin{tabular}{|c|c|c|c|c|c|c|c|c|}
\hline Author \& Year & Type of Lesion & Type of ISCI & Does of ISCI & $\begin{array}{l}\text { Number of } \\
\text { ISCI }\end{array}$ & $\begin{array}{l}\text { Intervals of } \\
\text { ISCI }\end{array}$ & $\begin{array}{c}\text { Result of } \\
\text { treatment }\end{array}$ & Follow up & Side effects \\
\hline $\begin{array}{l}\text { Alstergren et al., } \\
1996\end{array}$ & TMD & $\begin{array}{c}\text { methylprednisolone } \\
40 \mathrm{mg} / \mathrm{mL}+\text { lidocaine }\end{array}$ & $0 / 5-0 / 7 \mathrm{~mL}$ & 1 & - & $\begin{array}{c}\text { reduced signs and } \\
\text { symptoms and } \\
\text { NPY-LI }\end{array}$ & $6 \mathrm{w}$ & None \\
\hline $\begin{array}{l}\text { Bjørnland, } \\
\text { Gjaerum, } \\
\text { Møystad, } 2007 \\
\end{array}$ & TMD & $\begin{array}{l}\text { Betamethasone sodium } \\
\text { phosphate }+ \text { acetate }\end{array}$ & $0 / 7-1 \mathrm{~mL}$ & 2 & Biweekly & $\begin{array}{l}\text { reduce pain and } \\
\text { improve function }\end{array}$ & $6 \mathrm{~m}$ & $\begin{array}{l}\text { Temporary pain } \\
\text { after injections }\end{array}$ \\
\hline Lee et al., 2013 & $\begin{array}{c}\text { Langerhans cell } \\
\text { histiocytosis }\end{array}$ & $\begin{array}{c}\text { methylprednisolone, } \\
40 \mathrm{mg} / \mathrm{mL}\end{array}$ & $3 \mathrm{~mL}$ & 1 & - & complete resolution & $35 \mathrm{mo}$ & None \\
\hline Milián, 2001 & $\begin{array}{c}\text { Langerhans cell } \\
\text { histiocytosis }\end{array}$ & $\begin{array}{c}\text { Triamcinolone } \\
\text { acetonide }\end{array}$ & $25 \mathrm{mg}$ & 8 & every 3 weeks & complete resolution & $1 \mathrm{y}$ & none \\
\hline $\begin{array}{l}\text { Graham, Barret, } \\
\text { Goltz, } 1999\end{array}$ & Nodular fasciitis & $\begin{array}{c}\text { Triamcinolone } \\
\text { acetonide }(10 \mathrm{mg} / \mathrm{mL})\end{array}$ & $1.5 \mathrm{~mL}$ & 1 & - & completeresolution & $1 \mathrm{y}$ & None \\
\hline Kaplan, 2012 & $\begin{array}{c}\text { necrotizing } \\
\text { sialometaplasia } \\
\end{array}$ & $\begin{array}{c}\text { Dexamethasone }+ \\
2 \% \text { lidocaine }\end{array}$ & $10 \mathrm{mg}$ & 1 & - & $\begin{array}{c}\text { The lesion got } \\
\text { worsen. }\end{array}$ & $1 \mathrm{w}$ & None \\
\hline $\begin{array}{l}\text { Keogh et al., } \\
2004\end{array}$ & $\begin{array}{c}\text { necrotizing } \\
\text { sialometaplasia }\end{array}$ & Triamcinolone & $10 \mathrm{mg}$ & 3 & Weekly & $\begin{array}{c}\text { There was no } \\
\text { difference in the rate } \\
\text { of healing }\end{array}$ & $1 \mathrm{~m}$ & None \\
\hline $\begin{array}{l}\text { Picciani et al., } \\
2010\end{array}$ & RAS & $\begin{array}{c}\text { Betamethasone } \\
\text { dipropionate+ } \\
\text { disodiumphosphate }\end{array}$ & $\begin{array}{c}5 \mathrm{mg} / \mathrm{mL}+ \\
2 \mathrm{mg} / \mathrm{mL}\end{array}$ & 1 & - & $\begin{array}{c}\text { partial regression } \\
\text { in first week. No } \\
\text { recurrence in } 6 \\
\text { months }\end{array}$ & $6 \mathrm{~m}$ & None \\
\hline Xia et al., 2006 & Ulcerative OLP & $\begin{array}{l}\text { Triamcinolone } \\
(40 \mathrm{mg} / \mathrm{mL}\end{array}$ & $0 / 5 \mathrm{~mL}$ & 1 and 2 & biweek & $\begin{array}{l}\text { Relief of sign \& } \\
\text { symptoms and } \\
\text { reduction in size }\end{array}$ & 4 week & None \\
\hline Lee et al., 2013 & OLP & $\begin{array}{c}(40 \mathrm{mg} / \mathrm{mL}) \\
\text { Triamcinolone } \\
\text { acetonide }\end{array}$ & $0.5 \mathrm{~mL}$ & 5 & $\begin{array}{l}4 \text { weekly and } \\
1 \text { biweekly }\end{array}$ & $\begin{array}{c}\text { significantly } \\
\text { improve in pain and } \\
\text { burning mouth }\end{array}$ & $1 \mathrm{y}$ & $\begin{array}{l}\text { cushingoid } \\
\text { features. }\end{array}$ \\
\hline Liu et al., 2013 & OLP & $\begin{array}{l}\text { Betamethasone } \\
\text { Triamcinolone }\end{array}$ & $\begin{array}{l}1.4 \mathrm{mg} \\
8 \mathrm{mg}\end{array}$ & 2 & weekly & $\begin{array}{c}\text { Betamethasone } \\
\text { wes better than } \\
\text { triamcinolone }\end{array}$ & $3 \mathrm{~m}$ & None \\
\hline $\begin{array}{l}\text { Borahan, } \\
\text { Fisekcioglu, } \\
\text { Alpay, 2014 } \\
\end{array}$ & Erosive OLP & $\begin{array}{l}\text { Methylprednisolone } \\
\text { acetate }\end{array}$ & $0.1 \mathrm{cc}$ & 5 & biweekly & $\begin{array}{l}\text { significantly } \\
\text { improvement }\end{array}$ & & $\begin{array}{l}\text { Abscess formation } \\
\text { Mucosal atrophy }\end{array}$ \\
\hline $\begin{array}{l}\text { Metwalli et al., } \\
2018\end{array}$ & OLP & $\begin{array}{l}\text { Triamcinolone } \\
\text { acetonide }\end{array}$ & $20 \mathrm{mg} / \mathrm{mL}$ & 2 & weekly & $\begin{array}{c}\text { significantly } \\
\text { improvement but } \\
\text { no statistically } \\
\text { significant } \\
\text { differences with } \\
\text { BCG-PSN }\end{array}$ & $2 w$ & $\begin{array}{c}2 \text { case atrophy } \\
\text { and persistent } \backslash \\
\text { erythema }\end{array}$ \\
\hline $\begin{array}{l}\text { Tilakaratne, } \\
2016\end{array}$ & OSF & Methylprednisolone & $40 \mathrm{mg}$ & 6 & monthly & $\begin{array}{l}\text { improving mouth } \\
\text { opening }\end{array}$ & $1 \mathrm{y}$ & None \\
\hline
\end{tabular}


TABLE I - List of articles that applied ICSI to treatment oral lesions (cont.)

\begin{tabular}{|c|c|c|c|c|c|c|c|c|}
\hline Author \& Year & Type of Lesion & Type of ISCI & Does of ISCI & $\begin{array}{c}\text { Number of } \\
\text { ISCI }\end{array}$ & $\begin{array}{c}\text { Intervals of } \\
\text { ISCI }\end{array}$ & $\begin{array}{c}\text { Result of } \\
\text { treatment }\end{array}$ & Follow up & Side effects \\
\hline Singh, 2014 & OSF & $\begin{array}{c}\text { Betamethasone } \\
\text { Lycopene }\end{array}$ & $4 \mathrm{mg}$ & 16 & Twice weekly & $\begin{array}{c}\text { Lycopene is better } \\
\text { than betamethasone. }\end{array}$ & $4 \mathrm{~m}$ & None \\
\hline James, 2015 & OSF & $\begin{array}{l}\text { Dexamethasone+ } \\
\text { Hyaluronidase }+ \\
\text { Lignocaine HCL }\end{array}$ & $\begin{array}{c}1.5 \mathrm{~mL} \\
1500 \mathrm{IU} \\
0.5 \mathrm{~mL}\end{array}$ & 2 & biweekly & $\begin{array}{l}\text { Improvement in } \\
\text { mouth opening } \\
\text { Reduction in } \\
\text { burning sensation } \\
\text { and ulceration } \\
\end{array}$ & $9 \mathrm{~m}$ & None \\
\hline Kumar, 2007 & OSF & $\begin{array}{l}\text { Betamethasonee }+ \\
\text { Lycopene }\end{array}$ & $\begin{array}{l}21-\mathrm{mL} \text { ampules } \\
\text { of } 4 \mathrm{mg}\end{array}$ & 4 & biweekly & $\begin{array}{l}\text { Mouth opening was } \\
\text { increased more in } \\
\text { steroid group. }\end{array}$ & $6 \mathrm{~m}$ & None \\
\hline Singh, 2010 & OSF & $\begin{array}{c}\text { Hydrocortisone } \\
\text { acetate+ Hyaluronidase } \\
\text { Triamcinolone+ } \\
\text { Hyaluronidase }\end{array}$ & $\begin{array}{c}1.5 \mathrm{~mL} \\
1500 \mathrm{IU}\end{array}$ & 22 & Weekl & $\begin{array}{c}\text { Biweekly injections } \\
\text { was more } \\
\text { convenient because } \\
\text { of number of visits } \\
\text { and cost }\end{array}$ & $3 \mathrm{~m}$ & None \\
\hline $\begin{array}{l}\text { Nguyen, } \\
\text { Ahmed, } 2014\end{array}$ & $\begin{array}{l}\text { Pemphigus } \\
\text { vulgaris }\end{array}$ & $\begin{array}{l}\text { Triamcinolone } \\
\text { acetonidein } \\
2 \% \text { xylocaine } \\
\end{array}$ & $10-15 \mathrm{mg}$ & 4 & $\begin{array}{l}\text { Every three } \\
\text { weeks }\end{array}$ & $\begin{array}{l}\text { lesions resolved } \\
\text { within five to } \\
\text { sevendays. }\end{array}$ & $18 \mathrm{~m}$ & None \\
\hline $\begin{array}{l}\text { Abbas et al., } \\
2014\end{array}$ & $\begin{array}{l}\text { Pemphigus } \\
\text { vulgaris }\end{array}$ & $\begin{array}{c}\text { Triamcinolone }+ \\
2 \mathrm{~g} \text { cellcept }\end{array}$ & $10 \mathrm{mg} / \mathrm{mL}+$ daily & 2 & & $\begin{array}{c}\text { Resolving within } 2 \\
\text { months. }\end{array}$ & 1 year & None \\
\hline $\begin{array}{l}\text { Mignogna et al., } \\
2010\end{array}$ & $\begin{array}{l}\text { Pemphigus } \\
\text { vulgaris }\end{array}$ & $\begin{array}{l}\text { Triamcinolone } \\
\text { acetonide }\end{array}$ & $\begin{array}{c}40 \mathrm{mg} / \mathrm{mL} \\
\text { diluted } 2: 1 \text { with } \\
\text { saline (i.e. } \\
25 \mathrm{mg} / \mathrm{mL} \text { ) } \\
\text { per four lesions }\end{array}$ & $2-8$ & weekly & $\begin{array}{l}\text { Reducing time } \\
\text { of remission and } \\
\text { total number of } \\
\text { corticosteroids }\end{array}$ & 5.3 years & $\begin{array}{l}\text { Gingival pellets } \\
\text { and Candidiasis }\end{array}$ \\
\hline $\begin{array}{l}\text { Kalinska- } \\
\text { Bienias et al., } \\
2016\end{array}$ & MMP & Triamcinolone & $\begin{array}{l}0.3-2 \mathrm{~mL} \text { per } \\
\quad \text { erosion }\end{array}$ & 2- 18 & - & remission & $6-10 \mathrm{~m}$ & None \\
\hline $\begin{array}{l}\text { Leroux et al., } \\
2011\end{array}$ & Cluster headache & Cortivazol+ verapamil & $\begin{array}{l}3.75 \mathrm{mg} \text { in } \\
1.5 \mathrm{~mL}\end{array}$ & 3 & 48-72 hours & $\begin{array}{c}\text { Rapidly relief was } \\
\text { seen in steroid } \\
\text { group }\end{array}$ & $3-11 \mathrm{~m}$ & None \\
\hline $\begin{array}{l}\text { Gaul et al., } \\
2016\end{array}$ & Cluster headache & $\begin{array}{l}\text { Triamcinolone and } \\
\text { bupivacaine }\end{array}$ & $10 \mathrm{mg}$ & 1 & - & $\begin{array}{l}\text { Steroid ijectiois } \\
\text { an easy, safe and } \\
\text { effective }\end{array}$ & 60 days & None \\
\hline Sinha R, 2016 & Mucocele & $\begin{array}{l}\text { Betamethason } \\
4 \mathrm{mg} / \mathrm{mL}\end{array}$ & $1 \mathrm{~mL}$ & $2-4$ & weekly & $\begin{array}{l}18 \text { case complete } \\
\text { resolved, } 2 \text { case } \\
\text { Reduced in size }\end{array}$ & $6 \mathrm{~m}$ & Mild discomfort \\
\hline $\begin{array}{l}\text { Mortazavi et al., } \\
2017\end{array}$ & M ucocele & $\begin{array}{c}\text { dexamethasone }(8 \mathrm{mg} / 2 \\
\mathrm{mL}+\text { silk sutures })\end{array}$ & & 3 & weekly & Complete healing & $6 \mathrm{~m}$ & None \\
\hline $\begin{array}{l}\text { Baharvand } \\
\text { et al., } 2014\end{array}$ & Mucocele & $\begin{array}{c}8 \mathrm{mg} / \mathrm{mL} \\
\text { Dexamethasone }\end{array}$ & $1 \mathrm{~mL}$ & 3 & weekly & $\begin{array}{l}7 \text { case complete } \\
\text { resolved } 2 \text { case } \\
\text { Reduced in size }\end{array}$ & $(6-20 \mathrm{~m})$ & Mild discomfort \\
\hline $\begin{array}{l}\text { Mignogna et al., } \\
2004\end{array}$ & $\begin{array}{c}\text { orofacial } \\
\text { granulomatosis }\end{array}$ & $\begin{array}{l}\text { Triamcinolone } \\
40 \mathrm{mg} / \mathrm{mL}\end{array}$ & $1 \mathrm{~mL}(4 \mathrm{mg})$ & $2-3$ & weekly & $\begin{array}{l}\text { lip swellingsettle in } \\
\text { all patients with } 3 \\
\text { recurrences }\end{array}$ & $3-30 \mathrm{~m}$ & $\begin{array}{l}\text { Hypopigmentatior } \\
\text { of the upper lip } \\
\text { skin }\end{array}$ \\
\hline $\begin{array}{l}\text { Ravindran, } \\
\text { Karunakaran, } \\
2013\end{array}$ & $\begin{array}{c}\text { orofacial } \\
\text { granulomatosis }\end{array}$ & $\begin{array}{l}\text { Triamcinolone } \\
\text { acetonide }\end{array}$ & - & 2 & biweekly & $\begin{array}{l}\text { Improvement with } \\
\text { no recurrences }\end{array}$ & $1 \mathrm{y}$ & None \\
\hline $\begin{array}{l}\text { van der } \\
\text { Waal et al., } \\
2002\end{array}$ & $\begin{array}{c}\text { orofacial } \\
\text { granulomatosis }\end{array}$ & $\begin{array}{l}\text { Triamcinolone } \\
\text { acetonide }\end{array}$ & & Within 2-6 m & $\begin{array}{l}\text { biweekly to } \\
\text { monthly }\end{array}$ & $\begin{array}{l}\text { Patients responded } \\
\text { to ICSI. }\end{array}$ & $8.2 \mathrm{y}$ & None \\
\hline $\begin{array}{l}\text { Yang et al., } \\
2005\end{array}$ & $\begin{array}{c}\text { Plasma Cell } \\
\text { Cheilitis }\end{array}$ & $\begin{array}{l}\text { Triamcinolone } \\
\text { acetonide }\end{array}$ & $5.0-4.0 \mathrm{mg} / \mathrm{mL}$ & $2-4$ & biweekly & $\begin{array}{c}\text { lesions } \\
\text { healedcompletely }\end{array}$ & - & None \\
\hline $\begin{array}{l}\text { Tseng et al., } \\
2008\end{array}$ & $\begin{array}{l}\text { Plasma Cell } \\
\text { Cheilitis }\end{array}$ & $\begin{array}{l}\text { Triamcinolone } \\
\text { acetonide } \\
(2.5 \mathrm{mg} / \mathrm{mL}) .\end{array}$ & $0.1 \mathrm{~mL}$ & 2 & biweekly & healedcompletely & $1 \mathrm{y}$ & None \\
\hline Kaur et al., 2001 & $\begin{array}{l}\text { Plasma Cell } \\
\text { Cheilitis }\end{array}$ & $\begin{array}{c}\text { triamcinolone } \\
\text { acetonide } 10 \mathrm{mg} / \mathrm{mL}\end{array}$ & & 3 & biweekly & healedcompletely & $3 \mathrm{~m}$ & None \\
\hline $\begin{array}{l}\text { Ebrahimi, } \\
\text { Nader, Kendall, } \\
2016\end{array}$ & $\begin{array}{c}\text { trigeminal } \\
\text { neuralgia }\end{array}$ & & & 2 & & excellent pain relief & & \\
\hline
\end{tabular}


TABLE I - List of articles that applied ICSI to treatment oral lesions (cont.)

\begin{tabular}{|c|c|c|c|c|c|c|c|c|}
\hline Author \& Year & Type of Lesion & Type of ISCI & Does of ISCI & $\begin{array}{c}\text { Number of } \\
\text { ISCI }\end{array}$ & $\begin{array}{c}\text { Intervals of } \\
\text { ISCI }\end{array}$ & $\begin{array}{c}\text { Result of } \\
\text { treatment }\end{array}$ & Follow up & Side effects \\
\hline $\begin{array}{l}\text { Anjomshoaa } \\
\text { et al., } 2013\end{array}$ & $\begin{array}{c}\text { Follicular } \\
\text { Lymphoid } \\
\text { Hyperplasia }\end{array}$ & $\begin{array}{l}\text { Triamcinolone } \\
\text { acetonide }\end{array}$ & $40 \mathrm{mg}$ in $1 \mathrm{~mL}$ & 4 & weekly & $\begin{array}{l}\text { completely } \\
\text { resolved. }\end{array}$ & $7 \mathrm{~m}$ & none \\
\hline
\end{tabular}

\section{Caliber-Persistent Labial-Artery (CPLA)}

This lesion is an initial arterial branch that, without dividing and decreasing the diameter, can penetrate into subcutaneous tissue of the lips and create a noticeable palpable lesion. In 2016, Agha-Hosseini et al. reported a complete improvement of a lesion in the upper lip of patients following three triamcinolone injections (AghaHosseini, Sheykhbahaei, 2016).

\section{Hemangioma}

Hemangioma is known $t$ as the most common neonatal tumor that occurs at birth or during the first few weeks of birth in the head and the neck. The occurrence of this lesion in the oral mucosa is relatively rare and can affect the lips, cheeks, tongue, gums, mucous membranes, jawbones, and salivary glands (Chen, Yeong, \& Horng, 2000; Dilip, Madhukar, \& Prithviraj, 2016). Two studies in 1990 and 2008 also showed the significant effects of the ICSI treatment on parotid gland hemangiomas and subglottic hemangiomas (Meeuwis et al., 1990; Buckmiller, Francis, \& Glade, 2008).

\section{Lymphangioma}

Lymphangioma is a developmental tumor of the lymphatic origin. Lymphangioma is covered by endothelial cells and it often contains high vascular contents. Therefore, it can be treated with a similar mechanism of hemangioma (Farmand, Kuttenberger, 1996). A number of reports have been further registered on triamcinolone successful injection in the treatment of cystic hygroma and vascular malformations of the face and the head (Luo, Gan, 2013; Farmand, Kuttenberger, 1996).

Upregulating vasaconstrictor receptors on the vascular smooth muscle cells, increased production of angiotensin, augmented angiotensin converting enzyme (ACE) performance on vascular smooth muscles and endothelium, increased protein concentration of signal transmission from receptors, strengthened connection of signal transmission to receptor, increased intracellular vasaconstrictor production such as endothelin and decreased intracellular vasodilator production (AghaHosseini, Sheykhbahaei, 2016), tightened precapillary sphincters, and competition for estrogen receptors have been the proposed mechanisms for the effects of corticosteroids in the improvement of vascular lesions (Dilip, Madhukar, Prithviraj, 2016).

\section{Pyogenic Granuloma (PG)}

It is a benign, usually single, vascular lesion within the mouth that is found most commonly in the gum and the upper anterior teeth, but other areas of the mouth, such as the lips, tongue, and cheeks may also be involved. In this regard, two studies revealed the theraputic effects of corticosteroid injection in recurrent $\mathrm{PG}$ as well as PG in patients with GVHD; respectively (Parisi, Glick, Glick, 2006; de la Rosa-Garcia et al., 2006; AdenisLamarre et al., 2009). It seems that both anti-inflammatory effects and the above-mentioned mechanisms for the improvement of vascular lesions are helpful in improving PG.

\section{Central Giant Cell Granuloma (CGCG)}

This benign lesion in the jaw is limited to toothbearing areas, which sometimes shows a behavior similar to neoplasm (Motamedi et al., 2007). In cases wherein the lesion size is large and surgery can lead to functional or cosmetic defects and even bleeding during surgery, the ICSI can be much more effective. There have been also numerous recent reports of the beneficial impacts of the ICSI on the treatment of these lesions (Nogueira et al., 2010; Carlos, Sedano, 2002; Sezer et al., 2005; da Silva Sampieri et al., 2013; Dolanmaz et al., 2016). The use of the ICSI to treat this lesion was first proposed by Jacovay et al. (Rajeevan, Soumithran, 1998). Santos et al., in 2018, also reported the treatment of brown tumor 
associated with hyper-parathyroidism as a lesion which is clinicopathologically similar to CGCG (Dos Santos et al., 2018). Stimulated proliferation and differentiation of precursor cells into osteoclasts, inhibited activity of mature osteoclast cells, induced apoptosis of osteoclast-like cells, and the impeded extracellular production of lyzosomal proteases are the proposed mechanisms of the ICSI effect in the treatment of CGCG (Nogueira et al., 2010; Carlos, Sedano, 2002; da Silva Sampieri et al., 2013). It seems that the given method can be also employed to treat similar lesions with too much bleeding, such as peripheral giantcell granuloma (PGCG) and aneurysmal bone cyst (ABC). However, there have been no reports on the efficacy of this method in the treatment of these intra-oral lesions, although there are few reports about the treatment of $\mathrm{ABC}$ in other bones using the ICSI (Fraser, Coates, Cole, 1992; Gladden Jr et al., 2000).

\section{Glandular Cheilitis (GC)}

This is a chronic inflammatory process that involves the mucus salivary glands and their ducts which frequently occurs in the lower lip of adult males. It is not a naturally pre-malignant lesion (Haldar, 1976) and its clinical forms are simple, superficial suppurative and deep suppurative (Carrington, Horn, 2006). In 1976, complete treatment of this lesion was reported by the ICSI method (Haldar, 1976). In 2018, Sugaya demonstrated complete improvement of $\mathrm{GC}$ following two triamcinalone injections and $0.1 \%$ tacrolimus ointment application (Sugaya, Migliari, 2018).

\section{Temporomandibular Disorder (TMD)}

A group of patients with temporomandibular joint disorders experience pain, tenderness, and long-term motor limitations despite conservative treatments. In these situations, intra-articular corticosteroid injection is considered to improve the disease symptoms (Kopp et al., 1987). In this regard, different studies have examined the effects of this method on a variety of subjective symptoms, radiographic symptoms, as well as histological changes in the articulated tissues (El-Hakim, Abdel-Hamid, Bader, 2005). The anti-inflammatory effects of corticosteroids are also manifested through their effects on the release of neuropeptides from the end of neural fibers, inhibitory effects on the production of inflammatory mediators such as prostaglandin and leukotriene, and corticosteroid through the synthesis of lipoprotein as an inhibitory protein on phospholipase A2 (Agha-Hosseini, Sheykhbahaei, 2016; Alstergren et al., 1996). The potential side effects of intraarticular corticosteroid therapy include joint destruction, infection, and sometimes disease progression (El-Hakim, Abdel-Hamid, Bader, 2005; Kopp et al., 1985). Various investigations have further highlighted the benefits of the ICSI treatment in a variety of TMDs (Alstergren et al., 1996; Samiee et al., 2011; Stoll et al., 2012; Bjørnland, Gjaerum, Møystad, 2007).

\section{Granulomatosis disorder}

Orofacial granulomatous lesions are uncommon chronic conditions with multifactorial etiology and unexplained pathogenesis that mostly occur due to systemic conditions such as Crohn's disease, sarcoidosis, tuberculosis, or local causes such as chronic infections, foreign bodies, and allergies (Ravindran, Karunakaran, 2013). Clinically, they are usually in the form of a persistent or recurrent swelling that affects the lips. In addition, conditions such as Melkersson-Rosenthal syndrome and Miescher's cheilitis should be also considered among these lesions (Miest, Bruce, Rogers, 2016). A few recent studies on the positive effects of using the ICSI in treating such lesions were mentioned in Table (Ravindran, Karunakaran, 2013; Mignogna et al., 2004; Van Der Waal et al., 2002).

\section{Plasma-cell cheilitis}

This lesion is a benign idiopathic inflammatory condition, which is represented by dense infiltration of plasma cells in mucous and is usually shown as a plaque or patch with an eroded, flattened, or slightly raised and round surface. In patients with plasma-cell cheilitis, the degree of induced acanthosis in tissue appears to be an important factor determining the outcomes of treatment by topical corticosteroids (Yang et al., 2005; Tseng et al., 2009; Kaur et al., 2001).

\section{Lymphoid hyperplasia}

The lymphoid hyperplasia lesions are basically a propagation of benign lymphocytic reactivity with unclear etiology, usually seen as an exophytic mass of soft tissues with an intact surface in the areas of the mouth that have lymphoid tissues, such as the Waldeyer's tonsillar ring and the lateral border of the tongue and the palate. Follicular types are usually the same as the normal mucosal in color appearance; otherwise, they may be blue-black or purplered. These lesions have been often treated by a surgical procedure and through removal of the lesion with many complications, especially in the posterior regions of the mouth. However, one study in 2013 showed that the ICSI 
with the probable mechanism of inductions of apoptosis in activated $\mathrm{T}$ lymphocytes could easily treat these types of lesions with no complications (Anjomshoaa et al., 2013).

\section{Vesiculobullous disorder}

Vesiculobullous lesions are a category of chronic mucosal ulcers. In this respect, pemphigus vulgaris and benign mucous membrane pemphigoid (BMMP) is one of the most common lesions in the mouth. The primary treatment of these lesions is using the systemic corticosteroid, which can be employed in combination with immunosuppressive drugs. The ICSI in these lesions is not recommended during relapse/flare periods due to inadequate effects. It seems that the given method is the most effective one in the maintenance phase; as more than $70 \%$ of the lesions are improved and the systemic corticosteroid is getting tapered (Fortuna \& Mignogna, 2011; Mignogna et al., 2010; Nguyen \& Ahmed, 2014; Abbas et al., 2014; Kalinska-Bienias et al., 2016). In this respect, a study in 2018 demonstrated that the ICSI in combination with immunosuppressive drugs could lead to reduced dose of corticosteroids and shortened time of clinical improvements (Mignogna et al., 2010).

\section{Trigeminal neuralgia}

Trigeminal neuralgia is known as one of the most common causes of facial pains, which usually occurs as one-side sudden, severe, pulsating, recurrent, and diffused pain in one or more trigeminal branches. The ICSI is one of the proposed therapies in this painful disorder particularly in the trigger point of pain or involved neural branch blocks (Gronseth et al., 2008). There are also contradictory reports on the effectiveness of this method (Ebrahimi, Nader, Kendall, 2016; Elsheikh, Amr, 2016).

\section{Cluster headache}

Cluster headache is one of the most severe and debilitating types of primary headaches. Corticosteroid injection in the greater occipital nerve is also recognized as one of the theraputic options. Some of the reports on the positive effects of this treatment were presented in this study (Gaul et al., 2016; Leroux et al., 2011).

\section{Necrotizing sialometaplasia}

This is a rare inflammatory disease of the minor salivary gland that, in most cases, affects multiple glands in the hard palate due to an ischemic event. The lesion is self-limiting within 3 to 12 weeks and the supporting and symptomatic methods are considered as the basis for its treatment. Two studies in 2004 and 2012 showed that intralesional triamcinolone had no significant effect on the improvement of the lesion and, in some cases; it had exacerbated the necrosis (Kaplan et al., 2012; Keogh et al., 2004). It seems that trauma of drug injection, high doses of injectable substance, and lower keratinized tissue nature could reduce the acceptability of the substance and lead to more necrosis in this site or even no improvements. Accordingly, the ICSI was not recommended as a suitable method for the treatment of these lesions.

\section{Recurrent Aphthous Stomatitis (RAS)}

This is one of the most common oral ulcers with an approximate incidence rate of 5-50\% (Pakfetrat et al., 2010). In this respect, the ICSI reduces the symptoms, the course of the disease, and the period of normal mucus repair; but it does not affect the rate and the frequency of its recurrence (Picciani et al., 2010).

The role of the immune system in producing the RAS has been largely proven. The reduction in the proportion of $\mathrm{T}$ helper cells relative to T-cytotoxic cells and the special role of some types of human leukocyte antigens (HLAs) such as IL-IB and IL-6 have been wellillustrated. Steroids, through inhibition of lymphocyte $\mathrm{B}$ and effector T cells, can thus cut the response of these cells to accelerators such as allergies, trauma, and stress; and ultimately inflammatory processes can have palliative effects in improving symptoms in patients (Saravanan et al., 2014).

\section{Langerhans Cell Histiocytosis (LCD)}

This is a rare disease with unclear etiology, characterized by monoclonal proliferation of langerhans cells. Some believe that the LCD is a neoplastic process. These lesions inside the mouth can also affect soft tissues, hard tissues, or both (Esen et al., 2010). Routine treatment of this disease is also a major surgery with radiotherapy and chemotherapy, although in some cases self-healing has been also reported. The beneficial therapeutic benefits of the ICSI in the treatment of these lesions have been frequently reported (Esen et al., 2010; Putters et al., 2005; Lee, Yoon, 2013; Merglová et al., 2014). Even some studies have regarded it as the first line of treatment for the LCD due to fewer invasions as well as easier and cheaper prescriptions (Lee \& Yoon, 2013). Suppressing the langerhans cells, T lymphocytes, eosinophils, and osteoclast-like cells are the suggested mechanisms for 
the effect of this method on the treatment of these lesions (Esen et al., 2010).

\section{Nodular fasciitis}

This is a benign inflammatory fibroblastic lesion. It also has a relatively benign clinical behavior but it is similar to sarcoma in terms of histopathologic evaluations. Due to the rapid growth and infiltration in the muscles, radical surgery approach is needed. In this respect, a study (1999) reported the successful treatment of this lesion using the ICSI (Graham, Barret, Goltz, 1999).

\section{Mamelian target of rapamycine inhibitor- associated stomatitis}

Mamelian target of rapamycin (mTOR) is a serine/ threonine kinase that is essential for regulating cell growth and proliferation. Inhibition of this enzyme is one of the relatively new approaches in cancer management, as a target therapy. The side effects of this treatment include stomatitis, dermatitis, anorexia, nausea, and vomiting. Stomatitis is seen in the form of lesions that are quite similar to the RAS in the mouth (de Oliveira et al., 2011). Unlike mucositis caused by chemotherapy and radiotherapy, steroids are not good treatments for it, so the use of a variety of local, intralesional or systemic corticosteroids can be effective in the treatment of stomatitis induced by the mTOR inhibitor (de Oliveira et al., 2011; Peterson et al., 2016; Villa et al., 2015), even though some studies have reported selfimprovements without any interventions and treatments (Dominguez et al., 2000).

\section{Oral Lichen Planus (OLP)}

The OLP is known as one of the most common chronic inflammatory lesions within the mouth that can also affect skin, nails, hair, and other mucous membranes. Oral lesions are more resistant to treatments. In addition, lichenoid lesions with similar clinical manifestations can be created inside the mouth due to the use of drugs as well as contact with restorative or prosthetic materials. Regarding the role of immune system and autoreactive reactions in the etiopathogenesis of this disease, the use of various types of corticosteroids has been accepted as the first line treatment of this lesion (Agha-Hosseini et al., 2016). The use of the ICSI in the treatment of these lesions, especially those areas with more inflammations and manifestations such as erosion and ulcers, can be very effective in controlling the symptoms in patients (Lee et al., 2013; Xia et al., 2006; Borahan, Fisekcioglu,
Alpay, 2014; Liu et al., 2013). The effect of the ICSI in the treatment of the OLP in children has been also reported with no certain complications (De Moraes et al., 2011). In 2018, Metwalli reported the same effects of Bacillus Calmette-Guerin polysaccharide nucleic acid extract versus triamcinolone acetonide intralesional injection in the treatment of OLP (Metwalli et al., 2018).

\section{Mucocele}

Mucocell may occur through extravasation and retention phenomena in the salivary glands. Extravasation is caused due to salivary glandular duct rupture and retention is caused due to dilation of the gland duct. Nonsurgical therapies include cryosurgery, ICSI, sclerosing materials, lasers, and micro-crystallization. In this respect, corticosteroids seem to result in accumulation and contraction of the expanded duct of the salivary glands or induction of freezing similar to sclerosing agents (AghaHosseini, Sheykhbahaei, 2016; Mortazavi et al., 2014; Baharvand, Sabounchi, Mortazavi, 2014).

\section{Foreign Body Granuloma}

Entrance of any foreign materials into the oral mucosa such as suturing, restorative and abrasive materials, denture, anesthetic needle, injection of facial beauty gels or even bristles of toothbrushes can lead to chronic or acute inflammatory infiltration which produce granulomatous reactions. In this regard, a number of reports have been published about the beneficial effects of the ICSI in the treatment of granulomas in the lips (Shahrabi-Farahani et al., 2014; Jham et al., 2009).

\section{Lupus Erythematosus}

This is a multi-system inflammatory disease with rare oral manifestations (Netto et al., 2017). The oral manifestations in these patients can be seen as nonspecific ulcers or white and red plaques with discoid manifestations in different oral areas such as palate, cheeks, tongue, and gums. Although several studies have reported successful treatments of lupus skin lesions using the ICSI (Yaşar et al., 2017; Callen, 2006), no report was found on the use of oral lesion treatment via this method to be reviewed in this study.

\section{Graft-versus-Host Disease (GvHD)}

This is one of the main complaints following allogeneic transplant of hematopoietic stem cells. More 
than $80 \%$ of cases of this disorder can affect oral mucosa, in addition to involvement of several organs. Oral symptoms can be also present in acute phases as nonspecific ulcers but they can be similar to OLP, scleroderma, Sjögren syndrome, and dysgeusia in chronic phases. One of the theraputic options for oral GvHD lesions is corticosteroid. In this respect, one study was found reporting the use of the ICSI method in the treatment of the GvHD (Ohbayashi et al., 2007).

\section{Other Uses}

In addition to the above-mentioned applications of the ICSI for the treatment of intraoral lesions, corticosteroid injection is further employed in other dental conditions; e.g., controlling postoperative pain and swelling, increasing teeth movements in orthodontic treatments, and preventing esophageal stenosis after endoscopic dissection and joint stiffness after trauma (Zerener et al., 2015; Abtahi et al., 2014; Ohki et al., 2012; Efird et al., 2014).

\section{CONCLUSION}

The ICSI can be considered as one of the effective therapeutic methods with no significant problems in the treatment of many oral lesions such as inflammatory, immunologic, and vascular disorders. It can also have higher therapeutic effects than other topical forms of steroids and fewer side effects than systemic corticosteroids. According to the results of this study, further research studies are recommended to be conducted about the effects of this therapeutic approach in many common oral lesions.

\section{AUTHORSHIP}

Narges Gholizadeh: Conceived, planned, and carried out the experiments presented in the manuscript, or interpreted the data, or both.

Nafiseh Sheykhbahaei: Wrote the paper, or reviewed its successive drafts.

Maryam-Sadat Sadrzadeh-Afshar: Collected and assembled the data, and then approved the final draft.

\section{REFERENCES}

Abbas Z, Safaie Naraghi Z, Behrangi E. Pemphigus vulgaris presented with cheilitis. Case Rep Dermatol Med. 2014;2014:147197.
Abtahi M, Shafaee H, Saghravania N, Peel S, Giddon D, Sohrabi K. Effect of corticosteroids on orthodontic tooth movement in a rabbit model. J Clin Pediatr Dent. 2014;38(3):285-9.

Adenis-Lamarre E, Fricain J, Tabrizi R, Turlure P, Milpied $\mathrm{N}$, Beylot-Barry M. Massive pyogenic granuloma of the oral cavity during chronic graft-versus-host disease: treatment with local triamcinolone injection. Ann Dermatol Venereol. 2009;136(11):818-20.

Agha-Hosseini F, Sheykhbahaei N, Sadrzadeh-Afshar M. Evaluation of potential risk factors that contribute to malignant transformation of oral lichen planus: a literature review. J Contemp Dent Pract. 2016;17(8):692-701.

Agha-Hosseini F, Sheykhbahaei N. A new approach to the management of caliber-persistent artery: A case report and analysis of previously reported cases. Int J Dermatol. 2016;55(1):11-6.

Alstergren P, Appelgren A, Appelgren B, Kopp S, Lundeberg $\mathrm{T}$, Theodorsson $\mathrm{E}$. The effect on joint fluid concentration of neuropeptide $\mathrm{Y}$ by intraarticular injection of glucocorticoid in temporomandibular joint arthritis. Acta Odontol Scand. 1996;54(1):1-7.

Anjomshoaa I, Bulford LA, Dym H, Woo S.-B. Florid follicular lymphoid hyperplasia of the hard palatal mucosa managed with intralesional steroids: a case report and review of the literature. J Oral Maxillofac Surg. 2013;71(7):1202-8.

Baharvand M, Sabounchi S, Mortazavi H. Treatment of labial mucocele by intralesional injection of dexamethasone: case series. J Dent Mater Tech. 2014;3(3):128-133.

Bjørnland T, Gjaerum A, Møystad A. Osteoarthritis of the temporomandibular joint: an evaluation of the effects and complications of corticosteroid injection compared with injection with sodium hyaluronate. J Oral Rehabil. 2007;34(8):583-9.

Borahan MO, Fisekcioglu E, Alpay MS. A complication after intralesional methylprednisolone acetate application to oral mucosa: A case report. Balk J Dent Med 2014;18:154-156.

Buckmiller LM, Francis CL, Glade RS. Intralesional steroid injection for proliferative parotid hemangiomas. Int J Pediatr Otorhinolaryngol. 2008;72(1):81-7.

Callen JP. Cutaneous lupus erythematosus: a personal approach to management. Australas J Dermatol. 2006;47(1):13-27. 
Carlos R, Sedano HO. Intralesional corticosteroids as an alternative treatment for central giant cell granuloma. Oral Surg Oral Med Oral Pathol Oral Radiol Endod. 2002;93(2):161-166.

Carrington PR, Horn TD. Cheilitis glandularis: a clinical marker for both malignancy and/or severe inflammatory disease of the oral cavity. J Am Acad Dermatol. 2006;54(2):336-7.

Chen M, Yeong E, Horng S. Intralesional corticosteroid therapy in proliferating head and neck hemangiomas: a review of 155 cases. J Pediatr Surg. 2000;35(3):420-423.

Da Silva Sampieri MB, Yaedú RYF, Santos PSS, Goncales ES, Santa'ana E, Consolaro A, Cardoso LB. Central giant cell granuloma: treatment with calcitonin, triamcinolone acetonide, and a cystic finding 3 years and 6 months after the primary treatment. Oral Maxillofac Surg. 2013;17(3):229-34.

De La Rosa-Garcia E, Bologna-Molina R, Vega-González M, De Jesus T. Graft-versus-host disease, an eight case report and literature review. Med Oral Patol Oral Cir Bucal. 2006;11(6):E486-92.

De Moraes PC, Teixeira RG, Tacchelli DP, Bönecker M, Junqueira JLC, Oliveira LB. Atypical case of oral lichen planus in a pediatric patient: Clinical presentation and management. Pediatr Dent. 2011;33(5):445-7.

De Oliveira MA, Martins E Martins F, Wang Q, Sonis S, Demetri G, George S, Butrynski J, Treister NS. Clinical presentation and management of mTOR inhibitor-associated stomatitis. Oral oncol. 2011;47(10):998-1003.

Del Rosso J, Friedlander SF. Corticosteroids: options in the era of steroid-sparing therapy. J Am Acad Dermatol. 2005;53(1 Suppl 1):S50-8.

Dilip K, Madhukar N, Prithviraj K. Rare case of ulcerous lobular capillary haemangioma on the lateral side of the tongue. Int $\mathrm{J}$ Sci Res. 2016;5(11):52-54.

Dolanmaz D, Esen A, Mihmanlı A, Işık, K. Management of central giant cell granuloma of the jaws with intralesional steroid injection and review of the literature. Oral Maxillofac Surg. 2016;20(2):203-9.

Dominguez J, Mahalati K, Kiberd B, Mcalister VC, Macdonald AS. Conversion to rapamycin immunosuppression in renal transplant recipients: report of an initial experience. Transplantation. 2000;70(8):1244-1247.
Dos Santos B, Koth VS, Figueiredo MA, Salum FG, Cherubini $\mathrm{K}$. Brown tumor of the jaws as a manifestation of tertiary hyperparathyroidism: A literature review and case report. Spec Care Dentist. 2018;38(3):163-171.

Ebrahimi A, Nader A, Kendall M. (389) Treatment of refractory trigeminal neuralgia caused by head and neck radiation with ultrasound guided trigeminal nerve block. J Pain. 2016;17(4):S72.

Efird W, Kellam P, Yeazell S, Weinhold P, Dahners LE. An evaluation of prophylactic treatments to prevent post traumatic joint stiffness. J Orthop Res. 2014;32(11):1520-4.

Egbert JE, Paul S, Engel WK, Summers CG. High injection pressure during intralesional injection of corticosteroids into capillary hemangiomas. Arch Ophthalmol. 2001;119(5):677683.

El-Hakim I, Abdel-Hamid I, Bader A. Tempromandibular joint (TMJ) response to intra-articular dexamethasone injection following mechanical arthropathy: a histological study in rats. Int J Oral Maxillofac Surg. 2005;34(3):305-10.

Elsheikh N, Amr YM. Calcitonin as an additive to local anesthetic and steroid injection using a modified coronoid approach in trigeminal neuralgia. Pain Physic. 2016;19(7):45764.

Esen A, Dolanmaz D, Kalaycı A, Gunhan Ö, Avunduk MC. Treatment of localized Langerhans' cell histiocytosis of the mandible with intralesional steroid injection: report of a case. Oral Surg Oral Med Oral Pathol Oral Radiol Endod. 2010;109(2):e53-8.

Farmand M, Kuttenberger JJ. A new therapeutic concept for the treatment of cystic hygroma. Oral Surg Oral Med Oral Pathol Oral Radiol Endod. 1996;81(4):389-395.

Ffrooz A, Tehranchia-Nia Z, Ahmed A. Benefits and risks of intralesional corticosteroid injection in the treatment of dermatological diseases. Clin Exp Dermatol. 1995;20(5):363370 .

Fortuna G, Mignogna MD. Clinical guidelines for the use of adjuvant triamcinolone acetonide injections in oro-pharyngeal pemphigus vulgaris: the oral medicine point of view. J Oral Pathol Med. 2011;40(4):359-60. 
Fraser R, Coates C, Cole W. An angiostatic agent in treatment of a recurrent aneurysmal bone cyst. J Pediatr Orthoped. 1992;13(5):668-671.

Friedman SJ, Butler DF, Pittelkow MR. Perilesional linear atrophy and hypopigmentation after intralesional corticosteroid therapy: Report of two cases and review of the literature. J Am Acad Dermatol. 1988;19(3):537-41.

Gaul C, Roguski J, Dresler T, Abbas H, Totzeck A, Görlinger K, Diener H-C, Weber R. Efficacy and safety of a single occipital nerve blockade in episodic and chronic cluster headache: A prospective observational study. Cephalalgia. 2017;37(9):873880 .

Gladden Jr ML, Gillingham BL, Hennrikus W, Vaughan LM. Aneurysmal bone cyst of the first cervical vertebrae in a child treated with percutaneous intralesional injection of calcitonin and methylprednisolone: a case report. Spine. 2000;25(4):52730 .

Goldman L. Reactions following intralesional and sublesional injections of corticosteroids. JAMA. 1962;182(6):613-616.

Graham BS, Barrett TL, Goltz RW. Nodular fasciitis: response to intralesional corticosteroids. J Am Acad Dermatol. 1999;40(3):490-492.

Gronseth G, Cruccu G, Alksne J, Argoff C, Brainin M, Burchiel $\mathrm{K}$, et al. Practice Parameter: The diagnostic evaluation and treatment of trigeminal neuralgia (an evidence-based review) Report of the Quality Standards Subcommittee of the American Academy of Neurology and the European Federation of Neurological Societies. Neurology. 2008;71(15):1183-1190.

Haldar B. Cheilitis glandularis treated by injection of intralesional triamcinolone. Indian J Dermatol. 1976;21(3):53-4.

Hannon SM, Pickett AB, Frost JM. Foreign-body (silica) granuloma of the lip. J Oral Maxillofac Surg. 1983 Jul;41(7):4702.

Hengge UR, Ruzicka T, Schwartz RA, Cork MJ. Adverse effects of topical glucocorticosteroids. J Am Acad Dermatol. 2006;54(1):1-15.

James L, Shetty A, Rishi D, Abraham M. Management of oral submucous fibrosis with injection of hyaluronidase and dexamethasone in grade III oral submucous fibrosis: A retrospective study. J Int Oral Health. 2015;7(8):82-5.
Jham BC, Nikitakis NG, Scheper MA, Papadimitriou JC, Levy BA, Rivera H. Granulomatous foreign-body reaction involving oral and perioral tissues after injection of biomaterials: a series of 7 cases and review of the literature. J Oral Maxillofac Surg. 2009;67(2):280-5.

Kalinska-Bienias A, Kalowska M, Kwiek B, Jakubowska B, Ishii N, Hashimoto T, Kowalewski C, Wozniak K. Efficacy and safety of perilesional/intralesional triamcinolone injections in oral mucous membrane pemphigoid. Br J Dermatol. 2016;174(2):436-8.

Kaplan I, Alterman M, Kleinman S, Reiser V, Shuster A, Dagan Y, Shlomi B. The clinical, histologic, and treatment spectrum in necrotizing sialometaplasia. Oral Surg Oral Med Oral Pathol Oral Radiol. 2012;114(5):577-85.

Kaur C, Thami G, Sarkar R, Kanwar A. Plasma cell mucositis. J Eur Acad Dermatol Venereol. 2001;15(6):566-7.

Keogh P, O'regan E, Toner M, Flint S. Necrotizing sialometaplasia: an unusual bilateral presentation associated with antecedent anaesthesia and lack of response to intralesional steroids. Case report and review of the literature. Br Dent J. 2004;196(2):79-81.

Kopp S, Carlsson GE, Haraldson T, Wenneberg B. Long-term effect of intra-articular injections of sodium hyaluronate and corticosteriod on temporomandibular joint arthritis. J Oral Maxillofac Surg. 1987;45(11):929-35.

Kopp S, Wenneberg B, Haraldson T, Carlsson GE. The shortterm effect of intra-articular injections of sodium hyaluronate and corticosteroid on temporomandibular joint pain and dysfunction. J Oral Maxillofac Surg. 1985;43(6):429-35.

Kumar A, Bagewadi A, Keluskar V, Singh M. Efficacy of lycopene in the management of oral submucous fibrosis. Oral Surg Oral Med Oral Pathol Oral Radiol Endod. 2007;103(2):20713.

Laisuan W, Wongsa C, Dchapaphapeaktak N, Tongdee M, Chatmapanrangsee J, Rerkpattanapipat T. Anaphylaxis following intralesional triamcinolone acetonide (Kenacort) injection. Asia Pac Allergy. 2017;7(2):115-118.

Lee S-H, Yoon H-J. Intralesional infiltration of corticosteroids in the treatment of localized Langerhans cell histiocytosis of the mandible: report of two cases. Oral Surg Oral Med Oral Pathol Oral Radiol. 2013;116(4):e255-60. 
Lee YC, Shin SY, Kim SW, Eun YG. Intralesional injection versus mouth rinse of triamcinolone acetonide in oral lichen planus: a randomized controlled study. Otolaryngol Head Neck Surg. 2013;148(3):443-9.

Leroux E, Valade D, Taifas I, Vicaut E, Chagnon M, Roos C, Ducros A. Suboccipital steroid injections for transitional treatment of patients with more than two cluster headache attacks per day: a randomised, double-blind, placebo-controlled trial. Lancet Neurol. 2011;10(10):891-7.

Liu C, Xie B, Yang Y, Lin D, Wang C, Lin M, Ge L, Zhou, $\mathrm{H}$. Efficacy of intralesional betamethasone for erosive oral lichen planus and evaluation of recurrence: a randomized, controlled trial. Oral Surg Oral Med Oral Pathol Oral Radiol. 2013;116(5):584-90.

Luo Q-F, Gan Y-H. Pingyangmycin with triamcinolone acetonide effective for treatment of lymphatic malformations in the oral and maxillofacial region. J Craniomaxillofac Surg. 2013;41(4):345-9.

Meeuwis J, Bos C, Hoeve L, Van Der Voort E. Subglottic hemangiomas in infants: treatment with intralesional corticosteroid injection and intubation. Int J Pediatr Otorhinolaryngol. 1990;19(2):145-150.

Merglová V, Hrušák D, Boudová L, Mukenšnabl P, Valentová E, Hostička L. Langerhans cell histiocytosis in childhood-Review, symptoms in the oral cavity, differential diagnosis and report of two cases. J Cranio-Maxillofac Surg. 2014;42(2):93-100.

Metwalli MI, Marei AM, Toama MA, Soliman MI, Fawzy MM. Bacillus Calmette-Guerin polysaccharide nucleic acid extract versus triamcinolone acetonide intralesional injection in the treatment of oral lichen planus: a comparative study. Egyptian J Dermatol Venerol. 2018;38(1):1-11.

Miest R, Bruce A, Rogers R. Orofacial granulomatosis. Clin Dermatol. 2016;34(4): 505-513.

Mignogna M, Fedele S, Russo LL, Adamo D, Satriano R. Effectiveness of small-volume, intralesional, delayed-release triamcinolone injections in orofacial granulomatosis: a pilot study. J Am Acad Dermatol. 2004;51(2):265-268.

Mignogna M, Fortuna G, Leuci S, Adamo D, Dell'Aversana Orabona G, Ruoppo E. Adjuvant triamcinolone acetonide injections in oro-pharyngeal pemphigus vulgaris. J Eur Acad Dermatol Venereol. 2010;24(10):1157-1165.
Milián MA, Bagán JV, Jiménez Y, PérezA, Scully C, Antoniades D. Langerhans' cell histiocytosis restricted to the oral mucosa. Oral Surg Oral Med Oral Pathol Oral Radiol Endod. 2001;91(1):76-9.

Mortazavi H, Baharvand M, Alirezaei S, Noor-Mohammadi R. Combination therapy in a large lower lip mucocele: a non-invasive recommended technique. Dental Hypotheses. 2014;5(3):127-29.

Motamedi MH, Eshghyar N, Jafari SM, Lassemi E, Navi F, Abbas FM, Khalifeh S, Eshkevari PS. Peripheral and central giant cell granulomas of the jaws: a demographic study. Oral Surg Oral Med Oral Pathol Oral Radiol Endodontol. 2007;103(6):e39-e43.

Netto R, Janini MER, Meirelles Júnior VM, De Andrade BAB, Moura BDS, De Souza CG, Da Silva BA. Oral manifestation of systemic lupus erythematosus. Oral Surg Oral Med Oral Pathol Oral Radiol. 2017;124(2):e110-e111.

Nguyen T, Ahmed AR. Pemphigus vulgaris localized to the tongue. J Dermatol Case Rep. 2014;8(2):55-57.

Nogueira R, Teixeira R, Cavalcante R, Ribeiro R, Rabenhosrt $\mathrm{S}$. Intralesional injection of triamcinolone hexacetonide as an alternative treatment for central giant-cell granuloma in 21 cases. Int J Oral Maxillofac Surg. 2010;39(12):1204-1210.

Norris DA. Mechanisms of action of topical therapies and the rationale for combination therapy. J Am Acad Dermatol. 2005;53(1 Suppl 1):S17-S25.

Ohbayashi Y, Imataki O, Higuchi A, Miyake M, Ohue Y, Ohnishi H. Topical steroid injection for refractory oral chronic graftversus-host disease. [Rinsho ketsueki]. Jap J Clin Hematol. 2007;48(11):1508-1510.

Ohki T, Yamato M, Ota M, Takagi R, Murakami D, Kondo M, Sasaki R, Namiki H, Okano T, Yamamoto M. Prevention of esophageal stricture after endoscopic submucosal dissection using tissue-engineered cell sheets. Gastroenterology. 2012;143(3):582-588.e2.

Pakfetrat A, Mansourian A, Momen-Heravi F, Delavarian Z, Momen-Beitollahi J, Khalilzadeh O, Basir-Shabestari S. Comparison of colchicine versus prednisolone in recurrent aphthous stomatitis: A double-blind randomized clinical trial. Clin Invest Med. 2010;33(3):189-195. 
Parisi E, Glick P, Glick M. Recurrent intraoral pyogenic granuloma with satellitosis treated with corticosteroids. Oral Dis. 2006;12(1):70-72.

Peterson DE, O'Shaughnessy JA, Rugo HS, Elad S, Schubert MM, Viet CT, Campbell-Baird C, Hronek J, Seery V, Divers J. Oral mucosal injury caused by mammalian target of rapamycin inhibitors: emerging perspectives on pathobiology and impact on clinical practice. Cancer Med. 2016;5(8):1897-1907.

Picciani BLS, Silva-Junior GO, Barbirato DS, Ramos RT, Cantisano MH. Regression of major recurrent aphthous ulcerations using a combination of intralesional corticosteroids and levamisole: a case report. Clinics. 2010;65(6):650-652.

Putters TF, De Visscher J, Van Veen A, Spijkervet F. Intralesional infiltration of corticosteroids in the treatment of localised langerhans' cell histiocytosis of the mandible: Report of known cases and three new cases. Int J Oral And Maxillofac Surg. 2005;34(5):571-575.

Rajeevan N, Soumithran C. Intralesional corticosteroid injection for central giant cell granuloma: A case report. Int J Oral Maxillofac Surg. 1998;27:303-304.

Ravindran R, Karunakaran A. Idiopathic orofacial granulomatosis with varied clinical presentation. Case Rep Dent. 2013;2013:701749.

Richards RN. Update on intralesional steroid: focus on dermatoses. J Cutaneous Med Surg. 2010;14(1):19-23.

Sinha R, Sarkar S, Khaitan T, Kabiraj A, Maji A. Nonsurgical management of oral mucocele by intralesional corticosteroid therapy. Int J Dent. 2016;2016:2896748.

Samiee A, Sabzerou D, Edalatpajouh F, Clark GT, Ram S. Temporomandibular joint injection with corticosteroid and local anesthetic for limited mouth opening. J Oral Sci. 2011;53(3):321-325.

Saravanan T, Subha M, Prem P, Venkatesh A. Corticosteroids-its role in oral mucosal lesions. Int J Pharm Bio Sci. 2014;5:439-46.

Schetman D, Hambrick GW, Wilson CE. Cutaneous changes following local injection of triamcinolone. Arch Dermatol. 1963;88:820-828.

Sezer B, Koyuncu B, Gomel M, Gunbay T. Intralesional corticosteroid injection for central giant cell granuloma: a case report and review of the literature. Turk J Pediatr. 2005;47(1):75-81.
Shahrabi-Farahani S, Lerman MA, Noonan V, Kabani S, Woo S-B. Granulomatous foreign body reaction to dermal cosmetic fillers with intraoral migration. Oral Surg Oral Med Oral Pathol Oral Radiol. 2014;117(1):105-110.

Singh D, Shashikanth MC, Misra N, Agrawal S. Lycopene and intralesional betamethasone injections in the management of oral submucous fibrosis. J Indian Acad Oral Med Radiol 2014;26(3):264-8.

Singh M, Niranjan HS, Mehrotra R, Sharma D, Gupta SC. Efficacy of hydrocortisone acetate/hyaluronidase vs triamcinolone acetonide/hyaluronidase in the treatment of oral submucous fibrosis. ndian J Med Res. 2010;131:665-9.

Stoll ML, Good J, Sharpe T, Beukelman T, Young D, Waite $\mathrm{PD}$, Cron RQ. Intra-articular corticosteroid injections to the temporomandibular joints are safe and appear to be effective therapy in children with juvenile idiopathic arthritis. J Oral Maxillofac Surg. 2012;70(8):1802-1807.

Sugaya N, Migliari D. Cheilitis glandularis of both lips: successful treatment with a combination of an intralesional steroid injection and tacrolimus ointment. Case Rep Dent. 2018;2018:9169208.

Tilakaratne WM, Ekanayaka RP, Herath M, Jayasinghe RD, Sitheeque M, Amarasinghe H. Intralesional corticosteroids as a treatment for restricted mouth opening in oral submucous fibrosis. Oral Surg Oral Med Oral Pathol Oral Radiol. 2016;122(2):224-31.

Tseng JP, Cheng CJ, Lee WR, Wang KH. Plasma-cell cheilitis: successful treatment with intralesional injections of corticosteroids. Clin Exp Dermatol. 2009;34(2):174-177.

Van Der Waal RI, Schulten EA, Van Der Meij EH, Van De Scheur MR. Starink TM, Van Der Waal I. Cheilitis granulomatosa: overview of 13 patients with long-term follow-up-results of management. Int J Dermatol. 2002;41(4):225-229.

Villa A, Aboalela A, Luskin KA, Cutler CS, Sonis ST, Woo SB, Peterson DE, Treister NS. Mammalian target of rapamycin inhibitor-associated stomatitis in hematopoietic stem cell transplantation patients receiving sirolimus prophylaxis for graft-versus-host disease. Biol Blood Marrow Transplant. 2015;21(3):503-508. 
Xia J, Li C, Hong Y, Yang L, Huang Y, Cheng B. Short-term clinical evaluation of intralesional triamcinolone acetonide injection for ulcerative oral lichen planus. J Oral Pathol Med. 2006;35(6):327-331.

Yang JH, Lee UH, Jang SJ, Choi JC. Plasma cell cheilitis treated with intralesional injection of corticosteroids. J Dermatol. 2005;32(12):987-990.

Yaşar Ş, Kaynak E, Guneş P, Göktay F, Aytekin S. Atypical localization of necrobiosis lipoidica: involvement of the face and scalp. Skin Appendage Disord. 2017;3(2):92-94.
Zerener T, Aydintug YS, Sencimen M, Bayar GR, Yazici M, Altug HA, Misir AF, Acikel C. Clinical comparison of submucosal injection of dexamethasone and triamcinolone acetonide on postoperative discomfort after third molar surgery. Quintessence Int. 2015;46(4):317-26.

Received for publication on $07^{\text {th }}$ February 2018 Accepted for publication on $10^{\text {th }}$ October 2018 